Удк 631.6 .02

\title{
ВЛИЯНИЕ БЕСПОДСТИЛОЧНОГО НАВОЗА НА ЗАГРЯЗНЕНИЕ ОКРУЖАЮЩЕЙ СРЕДЫ ПРИ ЕГО ИСПОЛЬЗОВАНИИ В АГРОЛАНДШАФТАХ
}

\section{А. А. Волчек' ${ }^{1}$ Н. Н. Костюченко 2}

1 Д. геогр. н., профессор, декан фракультета инженерных систем и экологии учреждения образования «Брестский государственный технический университет», Брест, Беларусь, e-mail: volchak@tut.by ${ }^{2}$ Аспирант кафредры природообустройства учреждения образования «Брестский государственный технический университет», научный сотрудник Полесского аграрно-экологического института НАН Беларуси, Брест, Беларусь, e-mail: kost-n@rambler.ru

Ресрерат

В статье рассмотрено влияние различных факторов (рельеф, уровень залегания грунтовых вод, гранулометрический состав почв, дозы внесения удобрений) на загрязнение почв, поверхностных и грунтовых вод при использовании бесподстилочного навоза.

Ключевые слова: навоз, загрязнение, почвы, поверхностные воды, грунтовые воды.

\section{INFLUENCE OF LANDLESS MANURE ON POLLUTION ENVIRONMENTAL USE IN AGROLANDSCAPES}

\section{A. A. Volchek, N. N. Kostiuchenko}

Abstract

The article considers the influence of various factors (topography, groundwater level, soil granulometric composition, fertilizer application doses) on soil, surface and groundwater contamination when using litterless manure.

Keywords: manure, pollution, soil, surface water, groundwater.

\section{Введение}

На сегодняшний день одной из главных экологических проблем является проблема утилизации отходов, которые образуются в больших количествах и служат источником загрязнения окружающей среды. В 2019 г. в Республике Беларусь образовалось свыше 62,26 млн т отходов производства. Образование данных отходов на территории Беларуси неравномерно: без учета галитовых отходов, глинисто-солевых шламов и фоссрогипса 21,26 \% отходов образовалось на предприятиях Минской области; $18,69 \%$ - в Могилевской; $14,11 \%$ - в г. Минске; $13,99 \%$ в Гомельской; 18,43 \% - в Гродненской; 9 \% - в Брестской; 4,52 \% в Витебской. На предприятиях Брестской области преобладают отходы растительного и животного происхождения [1].

Одними из основных видов предприятий, наносящих наиболее существенный вклад в загрязнение среды, являются животноводческие комплексы. Это связано с тем, что на них образуется большое количество отходов, в первую очередь бесподстилочного навоза, который в общей структуре органических удобрений Республики Беларусь занимает более $40 \%$ [2, 3].

Одним из эффективных путей решения проблемы накопления отходов является их утилизация. Так как бесподстилочный навоз по своей природе является отходом животноводства, то использование его в агроэкосистеме может быть сопряжено с неблагоприятными экологическими последствиями, которые определяются свойствами отхода, спецификой его применения, свойствами почв [4].

В 2007 году в Беларуси принят Закон «Об обращении с отходами», действующий по сей день, в котором приоритетным направлением деятельности является использование отходов при условии соблюдения требований законодательства об охране окружающей среды и с учетом экономической эффеективности [5].

В том же году разработана и одобрена Советом Министров Национальная стратегия устойчивого социально-экономического развития Республики Беларусь на период до 2030 г., в которой для рационального использования природно-ресурсного потенциала республики среди приоритетных направлений деятельности определены: сохранение плодородия почвенных ресурсов, ренатурализация низкопродуктивных земель сельскохозяйственного назначения, повышение эффективности использования и охраны земельных ресурсов, оценка влияния природных и антропогенных факторов на водные ресурсы, минимизация загрязнения поверхностных водных объектов [6]. В этом же документе уделяется внимание проблеме образования и использования отходов и рекомендуется максимальное их вовлечение для производства продукции и энергии.

Таким образом, с целью минимизации экологических рисков и охраны окружающей среды требуется оценить степень загрязнения почвы, водных объектов при использовании бесподстилочного навоза в процессе агропроизводства, а также разработать рекомендации по рациональному использованию природных ресурсов при производстве сельскохозяйственной продукции.

\section{Основная часть}

В 70-80-е годы XX в. в Беларуси происходил перевод животноводства на промышленную основу. В это время строились и вводились в эксплуатацию животноводческие комплексы на несколько тысяч голов крупного рогатого скота и на несколько десятков тысяч свиней [7]. Однако при строительстве не принимались во внимание климатические, гидрографические и почвенные условия. Параметры комплексов южной зоны переносились механически в северную и северно-восточную зоны [8]. Располагаясь в специфических природноэкологических условиях и занимая определенное положение относительно водоемов и водотоков, места животноводческих предприятий имели свои особенности воздействия на окружающую среду [7].

На животноводческих комплексах ежегодно накапливается около 20 млн м ${ }^{3}$ жидкого навоза и навозных стоков [9]. Количество навоза зависит от множества причин: возраста животных, типа и интенсивности кормления, способа содержания животных, объема технологических вод, поступающих в навоз, технологии удаления и накопления навоза. Фактический выход бесподстилочного навоза превышает расчетные значения в несколько раз, что обусловлено несовершенством применяемых систем удаления навоза из помещений, попаданием в каналы воды при мойке помещений и животных и др. факторов [10].

Огромное скопление сырого навоза представляет угрозу загрязнения первоначально в районе расположения животноводческого комплекса, а в дальнейшем может распространиться на обширную территорию. Хранение навоза в необорудованных навозохранилищах приводит к загрязнению почвы, грунтовых и поверхностных вод [11] Загрязнение подземных вод происходит в результате фильтрации из навозохранилищ, а также в случае внесения в почву доз необработанного бесподстилочного навоза. Это вызывает серьезную тревогу, т. к. подземные воды питают водозаборы и сообщаются с открытыми водоемами [12]. Наибольшую опасность представляют навозонакопители, устраиваемые на склонах, в оврагах и балках, сток по которым может поступать в открытую речную сеть. В паводковый период такие сооружения перехватывают поверхностный сток, происходит их переполнение, земляные плотины разрушаются, и навозная жижа из накопителей поступает в расположенные ниже водоемы [13].

С полей вместе с выпадающими осадками навоз попадает в открытые водоемы и подземные источники. Из-за поступления больших количеств азота, фосфора и других биогенных элементов происходит 
Вестник Брестского государственного технического университета. 2021

эвтрофирование водных объектов, характеризующееся активным ростом водорослей, планктона. Отмирая и разлагаясь, они снижают запасы растворенного кислорода, способствуют появлению в воде аммиака, сероводорода, увеличению концентрации свободной углекислоты, железа и других веществ, что вызывает ухудшение физикохимических и органолептических показателей природной воды, приводит к массовому замору рыб и причиняет значительный экономический ущерб. Помимо этого, ухудшение качества воды в результате эвтрофирования способствует разрушению материалов, применяемых в гидротехническом строительстве [14]. Источником поступления биогенных веществ в водоемы являются и фосфатные компоненты синтетических моющих средств, применяемых для очистки помещений [15].

Исследования Л. В. Кирейчевой показали, что в настоящее время отсутствуют репрезентативные сведения о составе диффузионного стока с сельскохозяйственных мелиорируемых земель. В результате исследований ею установлено, что со сбросом дренажных вод с мелиорируемого массива, объем которых в 1,3 раза больше поверхностного стока с сельскохозяйственных полей вынос биогенных веществ составляет $78 \%$ от общего диффузного загрязнения. Основными загрязнителями являются азотные соединения, составляющие более 30 \% общего объема, из них почти 80 \% выносится с дренажным стоком [16]

Отрицательное воздействие на окружающую среду оказывает внесение повышенных доз удобрений в почву. При недостатке площадей утилизации, топливных ресурсов, а также неравномерном распределении удобрений в результате износа техники происходит накопление избыточного количества питательных веществ в почве, что приводит к снижению урожайности сельскохозяйственных культур, загрязнению растениеводческой продукции, почв нитратами, хлоридами и другими соединениями.

Экологи Европы считают, что основной причиной образования азотсодержащих кислотных дождей является нарушение технологии хранения и внесения органических удобрений. В некоторых европейских странах приняты законы о необходимости их хранения в закрытых накопителях анаэробного типа, обязательном внутрипочвенном внесении данных удобрений [17].

Особую опасность для экологической обстановки представляют содержащиеся в навозе остаточные количества дезинфицирующих веществ, антибиотиков, транквилизаторов применяемых на крупных животноводческих комплексах в целях санитарной обработки производственных помещений и профилактики заболеваний животных. Кроме того, в навозе и стоках присутствуют патогенные микроорганизмы, вызывающие заболевания животных и человека [12]. Остаточные количества антибиотиков подавляют биологическую активность почвы, процессы гумусообразования [17]. Внесение в почву навоза от животных, прошедших лечение антибиотиками, ослабляется ее способность к самообеззараживанию. Обычно 90 \% патогенных кишечных палочек в данных почвах являются устойчивыми к воздействию антибиотиками [18]. Поэтому использовать стоки в качестве удобрений можно лишь после соответствующей подготовки и обеззараживания [19].

Увеличение нагрузки на окружающую среду отмечается также при нарушении срока внесения органических удобрений. Наиболее опасным в экологическом отношении является несоблюдение требований зимнего внесения органических удобрений. При высоте снежного покрова более $20 \mathrm{~cm}$, температуре воздуха ниже $-10^{\circ} \mathrm{C}$ на полях с выраженным микрорельефом наблюдаются большие потери удобрений, загрязнение поверхностных и грунтовых вод. Вместе с талыми водами из органических удобрений теряется до $25 \%$ азота, свыше $10 \%$ фосфора, 15 \% калия, наблюдается также загрязнение почв, артезианских питьевых источников болезнетворными микроорганизмами, яйцами гельминтов [17].

В республике Беларусь мониторинг экологического состояния почв, используемых предприятиями интенсивного животноводства, проводится в очень ограниченном объеме. Фрагментарные исследования земель некоторых животноводческих комплексов показали, что при ежегодном использовании огромных доз жидких навозных стоков на ограниченных площадях не обеспечивается экологически безопасное состояние почвенного покрова.

Геохимическое обследование почв, используемых свинокомплексом «Южное» Брестской области, показали, что неравномерное распределение навозных стоков по территории обусловило загрязнение сельскохозяйственных земель нитратами и в меньшей степени тяжелыми металлами. Причем, в зависимости от дозы внесения эти показатели сильно различаются [19].

Отрицательно сказывается на полях утилизации жидких органических удобрений наличие микропонижений. Данная особенность микрорельефа приводит к перераспределению питательных веществ по площади, что, в свою очередь, влияет на качество грунтовых вод $[19,20]$. Исследования показали, что коэффициент варьирования содержания в подземных водах кальция и нитратов возросло на участках микропонижений в 5 раз по сравнению с ровной поверхностью [21]. Кроме того, с поверхностным стоком может теряться $30 \%$ азота и 17 \% фоссрора, содержащихся в жидких органических удобрениях. Одним из путей сокращения потерь является выравнивание поверхности почв и соблюдение научно обоснованного режима орошения, исключающего превышение поливных норм. Не соблюдение этого в отдельных случаях привело к тому, что содержание нитратов в грунтовых водах превышало предельно допустимую концентрацию (ПДК). Наряду с ними вымывался также аммоний.

Серьезное осложнение экологической обстановки создает микрорельеф на тяжелых почвах, а также на полях, прилегающих к навозохранилищам. В микрозападинах накапливается, прежде всего, фосфор, где в слое почвы 0-20 см содержание его подвижных форм достигает 740 мг/кг [22]. Что касается нитратного азота, то в слое супесчаной почвы 0-6 м на фоне высоких доз отходов свинокомплекса его количество превысило 2 т/га [23].

Результаты исследований Г. Е. Мерзлой показали, что внесение повышенных доз бесподстилочного навоза способствует накоплению нитратов в почвенном профиле до глубины 4,5 м [24].

Почвы, загрязненные животноводческими стоками, служат источником фрормирования экологически опасной растениеводческой продукции, в которой наблюдается низкое сахаропротеиновое соотношение, высокое содержание нитратов, ухудшается минеральный состав кормов [19], что оказывает негативное влияние на состояние животных.

Исследования по влиянию животноводческих комплексов на окружающую среду Притятского Полесья, проведенные М. И. Струком, выявили, что в химическом загрязнении почв, грунтовых и поверхностных вод навозными стоками принимают участие главным образом соединения азота аммиачного, нитритного, нитратного, органического, а также хлориды, сульфаты, фосфаты.

В регионе Припятского Полесья существует повышенная опасность загрязнения грунтовых вод, что обусловлено преобладанием в его ландшафтной структуре низинных природных комплексов, сложенных легко проницаемыми песчаными отложениями с близким к поверхности залеганием данных вод. Наиболее высокую опасность к загрязнению грунтовых вод представляет западная часть региона, включая три района Брестской (Лунинецкий, Пинский, Столинский) и Житковичский район Гомельской области. Данные объекты являются приоритетными для создания вокруг них санитарно-защитных зон и контроля за соблюдения должного санитарного состояния на непосредственно занимаемой ими территории [7].

Пахотные земли Полесского региона характеризуются большим разнообразием по уровню плодородия. В основном это легкие по гранулометрическому составу почвы (рыхлосупесчаные и песчаные) отличающиеся низкой влагоемкостью, недостаточным содержанием элементов питания, поэтому получение высоких урожаев сельскохозяйственных культур возможно только при условии достаточного внесения минеральных и органических удобрений [25], что является дополнительным источником поступления в поверхностные воды основных биогенных веществ - азота и фоссфора [26]. Песчаные и супесчаные почвы способствуют относительно быстрому проникновению биогенных элементов на уровень грунтовых вод $[27,28]$. На суглинистых почвах загрязнение грунтовых вод происходит менее интенсивно, чем на супесчаных, вследствие их лучшей адсорбционной способности [29, 30].

Азот, содержащийся в бесподстилочном навозе, преобладает в аммонийной форме. Попадая в почву, он окисляется до нитратов, которые характеризуются высокой миграционной способностью и легко проникая через зону аэрации загрязняют грунтовые воды. Помимо гранулометрического состава почвы интенсивность миграции нитратов зависит от количества выпадающих осадков, поливной нормы и уровня залегания грунтовых вод. Чем ближе грунтовые воды к поверхности почвы, тем сильнее они загрязняются нитратами $[3,31]$. Грунтовые воды, находящиеся под чрезмерно удобряемой почвой, содержат нитраты в концентрациях более $1000 \mathrm{mг/л}$, что может быть опасно для человека.

Мониторинг на территории ОАО «СГЦ «Западный» Брестского района показал, что на полях орошения навозными стоками свинокомплекса ХПК (химическое потребление кислорода) и содержание аммония в грунтовых водах превышали ПДК соответственно в 10 и 74 раза. Основная причина - избыточное внесение в почву животноводческих стоков [32].

Исследования, выполненные В. И. Желязко и П. Ф. Тиво, показывают, что при внесении бесподстилочного навоза с поливной нормой 
Вестник Брестского государственного технического университета. 2021

500-700 м3/га содержание $\mathrm{NO}^{3-}$ в грунтовых водах на глубине 1,5 м возрастает до 24-30 мг/л, в то время как в контрольном варианте $4 \mathrm{мг/л.} \mathrm{Наиболее} \mathrm{подвижными} \mathrm{из} \mathrm{компонентов} \mathrm{стоков} \mathrm{являются} \mathrm{хло-}$ риды и нитраты. Достаточно интенсивно вымывается и кальций. Калий интенсивнее поглощается растениями, поэтому вымывается по сравнению с натрием намного слабее. Порядок выщелачивания основных катионов по возрастанию из почвенного профиля при орошении стоками следующий: $\mathrm{Ca}^{2+}>\mathrm{Na}^{+}>\mathrm{Mg}^{2+}>\mathrm{K}+>\mathrm{NH}^{4+}$. Из микроэлементов более интенсивно вымывается цинк.

По данным вышеуказанных ученых содержание нитратов в первые 2-3 года после внесения бесподстилочного навоза не превышает ПДК. Однако ухудшение качества грунтовых вод растянуто во времени и может наблюдаться спустя 7 и более лет с момента загрязнения. При наличии гидравлической связи между водоносными горизонтами и открытыми водоемами следует избегать избыточных доз внесения бесподстилочного навоза. В данном случае на 5-6 год при внесении жидких органических удобрений (свыше 300 кг/га азота) содержание нитратов в грунтовых водах на глубине 3-4 м превысило 100 мг/дм³ ${ }^{3}$ что выше ПДК в 2,2 раза (ПДК 45 мг/дм³) [3].

Фосфрор обычно фиксируется в пахотном слое почвы. На супесчаных почвах, подстилаемых песками, при высоких дозах внесения органики, возможна миграция фосфора в более глубокие почвенные горизонты, что обусловлено большей миграционной способностью органических соединений данного элемента по сравнению с минеральными [33].

На черноземе темно-коричневом суглинистом не наблюдается вымывания элементов из почвы, поэтому риск загрязнения грунтовых и поверхностных вод отходами жизнедеятельности животных оценивается как низкий [34].

Во избежание загрязнения грунтовых вод Н. В. Клебанович рекомендует следующие предельно допустимые дозы бесподстилочного навоза, рассчитанные по азоту для различных почв: на суглинистых почвах - 250 кг/га в год, на супесчаных - 200-230 кг/га и на песчаных - 160-180 кг/га. При этом на участках с значительным уклоном не следует вносить бесподстилочный навоз [33].

По мнению П. Ф. Тиво нормы жидких органических удобрений в расчете на азот на дерново-подзолистых почвах при орошении даже многолетних трав не должны превышать 240-270 кг/га с внесением их дробными дозами под каждый укос [9].

В странах EC доза азота органических удобрений ограничивается $170 \mathrm{kг/га} \mathrm{[17].} \mathrm{Нормы} \mathrm{внесения} \mathrm{азота} \mathrm{В} \mathrm{России} \mathrm{представлень}$ в таблице $1[17,35]$.

Таблица 1 - Дозы внесения азота органических удобрений, используемые в России

\begin{tabular}{|l|c|}
\hline \multicolumn{1}{|c|}{ Сельскохозяйтвенные культуры } & $\begin{array}{c}\text { Дозы азота органических } \\
\text { удобрений, кг/га }\end{array}$ \\
\hline Яровые зерновые и однолетние травы & $120-180$ \\
\hline $\begin{array}{l}\text { Сахарная свекла, злаковые и злаково- } \\
\text { бобовые многолетние травы }\end{array}$ & $200-300$ \\
\hline Кукуруза на зеленый корм & $200-320$ \\
\hline Озимые зерновые & $120-140$ \\
\hline Столовый картофель & $120-200$ \\
\hline Озимые промежуточные культуры & $100-120$ \\
\hline Кормовая свекла & $200-320$ \\
\hline Орошаемое культурное пастбище & $300-360$ \\
\hline
\end{tabular}

Особую опасность для агроландшафта представляют тяжелые металлы. Содержание кадмия, ртути, свинца в окружающей среде постоянно растет. Попадая в почву, тяжелые металлы накапливаются в ней, образуя высокотоксичные соединения, загрязняющие окружающую среду, значительно ухудшая качество корма [36]. Наибольшую экологическую опасность представляет кадмий, как наиболее высокотоксичный и мобильный элемент [37-39].

Загрязнение почв происходит в основном через атмосферу путем осаждения паров аэрозолей, пыли и растворенных соединений токсических веществ с дождем и снегом [40]. Тяжелые металлы поступают в почву также с минеральными удобрениями, осадками сточных вод, различными компостами из бытового мусора, протравителями семян. Источником токсических веществ является и бесподстилочный навоз. Это объясняется тем, что комбикорма обогащаются фосфатами, содержащими в качестве примесей кадмий. Для повышения продуктивности животных в корма добавляют цинк и медь. Таким образом, через корм тяжелые металлы попадают в навозные стоки, затем в почву и растения [17]. Тяжелые металлы содержатся и в подстилочном навозе, известковых удобрениях [41].
Умеренное применение жидких органических удобрений не приводит к интенсивному загрязнению природной среды тяжелыми металлами. В результате исследований, проведенных в Ивановском районе Брестской области, установлено, что эти соединения преимущественно располагаются в пахотном слое. Причем отмеченная закономерность проявляется как на минеральных, так и на торффяных почвах [17].

Особенно слабой способностью к утилизации тяжелых металлов характеризуются песчаные и супесчаные разновидности почв подзолистого типа, отличающиеся малой бусрерностью, высокой кислотностью и преобладанием окислительных условий среды [42]. При внесении дозы стоков с содержанием азота 480 кг/га отмечается заметное повышение содержания подвижных соединений цинка и кадмия в пахотном слое, что позволяет такие почвы рассматривать как ближайший резерв формирования земель, загрязненных тяжелыми металлами.

С увеличением норм вносимых животноводческих стоков на суглинистых почвах подвижные формы тяжелых металлов накапливаются в почвенном слое, что свидетельствует о более надежной защите подземных вод от загрязнения, в отличие от песков и рыхлых супесей Белорусского Полесья [19].

Поступление тяжелых металлов в растения резко снижается при содержании гумуса в почве более $3 \%$, так как гуминовые вещества связывают тяжелые металлы в нерастворимые малоподвижные комплексы, уменьшая их биодоступность и экотоксичность $[43,44]$.

Результаты многочисленных исследований по технологии использования навозных стоков для удобрительного орошения с учетом природоохранных мероприятий показывают, что при обоснованном режиме удобрительных поливов достигается высокое качество почвенной очистки стоков [45]. Одновременно с этим обеспечивается возможность вовлечения в сельскохозяйственный оборот малопродуктивных и бросовых земель [3].

\section{Заключение}

Несмотря на большой опыт использования бесподстилочного навоза в растениеводстве на мелиорируемых агроландшафтах Беларуси применяемые технологии требуют дальнейшего совершенствования с учетом рельефа местности, свойств почв и их гранулометрического состава, состава навоза и экологических условий территории.

Наличие в Белорусском Полесье легких по гранулометрическому составу почв обуславливает повышенную опасность загрязнения окружающей среды. Недостаточное количество натурных исследований, отсутствие крупномасштабного мониторинга экологического состояния почв, поверхностных и грунтовых вод вблизи животноводческих предприятий вызывает необходимость исследования степени загрязнения окружающей среды, и разработки рациональных экологически безопасных способов использования бесподстилочного навоза в земледелии.

Несоблюдение требований, предъявляемым к качеству органических удобрений, условиям хранения, применения, а также отсутствия должного контроля за сельскохозяйственными землями при утилизации бесподстилочного навоза может явиться причиной появления зон чрезвычайной экологической ситуации или экологического бедствия.

\section{Список цитированных источников}

1. Обращение с отходами [Электронный ресурс] / Министерство природных ресурсов и охраны окружающей среды Респуб. Беларусь. - Минск, 2021. - Режим доступа : http://www.minpriroda.gov.by. - Дата доступа : 12.01.2021.

2. Кузнецов, Е. В. Переработка отходов животноводческих предприятий / Е. В. Кузнецов // Электронный сетевой политематический журнал «Научные труды КубГТУ». - 2019. - № 3. - С. 864-873.

3. Желязко, В. И. Использование бесподстилочного навоза на мелиорируемых агро-ландшафтах. Теория и практика : монография / В. И. Желязко, П. Ф. Тиво. - Минск, 2006. -296 с.

4. Дабахова, Е. В. Агроэкологические проблемы использования органических удобрений в сельском хозяйстве / Е. В. Дабахова, И. А. Питина // Агрохимический вестник. - 2017. - №2. - С. 10-14.

5. Об обращении с отходами: Закон Респ. Беларусь, 20 июля 2007 г., №271-3 в ред. Закона Респ. Беларусь от 02 апреля 2019 г. // Консультант Плюс: Беларусь [Электронный ресурс] / Нац. центр правовой информ. Респ. Беларусь. - Минск, 2020.

6. Национальная стратегия устойчивого социально-экономического развития Республики Беларусь на период до 2030 года [Электронный ресурс]. - 2017. - Режим доступа : https://www.economy.gov.by/uploads/files/NSUR2030/Natsionalnaja-strategija-ustojchivogo-sotsialno-ekonomicheskogo-razvitija-Respubliki-Belarus-na-period-do-2030-goda.pdf. - Дата доступа : 27.12.2020. 
Вестник Брестского государственного технического университета. 2021

7. Струк, М. И. Оценка средоформирующей роли объектов животноводства в Припятском Полесье / М. И. Струк // Природопользование. - 2015. - № 27. - С. 24-32.

8. Бадьина, В. М. Загрязнение почв и их охрана / В. М. Бадьина // Эколого-экономические проблемы реформирования агропромышленного комплекса Белорусского Полесья. - 2001. - Вып.1. C. $212-220$.

9. Тиво, П. Ф. Экологические аспекты использования бесподстилочного навоза / П. Ф. Тиво [и др.] // Мелиорация. - 2010. - № 2 (64). - C. 129-138.

10. Дыба, Е. В. Обзор и анализ известных способов внесения жидкого навоза / Е. В. Дыба, Ю. Л. Салапура // Научно-технический прогресс в сельскохозяйственном производстве : материалы Междунар науч.-технич. конф., посвящ. 70-летию со дня образования РУП «НПЦ НАН Беларуси по механизции сельского хозяйства», Минск, 18-20 окт. 2017 г / Беларуская навука. - Минск, 2017. - С. 185-189.

11. Давыдов, А. С. Использование бесподстилочного навоза для удобрительных поливов / А. С. Давыдов, Р. П. Воробьева // Природообустройство. - 2008. - № 4, - С.25-28.

12. Миронов, В. В. Вопросы защиты окружающей среды от загрязнений отходами животноводства и птицеводства / В. В. Миронов // Инновации в сельском хозяйстве. - 2016. - № 5 (20). - С. 56-59.

13. Степук, Л. Я. О необходимости активизации решения экологических проблем вокруг животноводческих комплексов / Л. Я. Степук, А. Н. Кавгареня // Современные технологии и комплексь технических средств в сельскохозяйственном производстве материалы Междунар. науч.-практич. конф., Минск, 2005 / УО БГАТУ; под общ. ред. Л. В. Мисуна. - Минск, 2005. - С. 165-167.

14. Система применения удобрений / С. Ф. Шекунова [и др.]. - Горки Белорусская государственная сельскохозяйственная академия, 2004. -135 c.

15. Скопинцева, Т. В. Проблемы борьбы с эвтрофрикацией водоемов в случае сброса фосфорсодержащих сточных вод / Т. В. Скопинцева, А. Г. Синельников // Фундаментальные и прикладные исследования в современном мире. - 2014. - Том 3, № 8. - С. 27-30.

16. Кирейчева, Л. В. Оценка диффузного загрязнения от сельскохозяйственных территорий в бассейне Верхней Волги и разработка мероприятий / Л. В. Кирейчева [и др]. // Водные ресурсы. - 2020. Том 47, № 5. - С. 523-535.

17. Тиво, П. Ф. Загрязнение окружающей среды тяжелыми металлами, содержащимися в животноводческих стоках / П. Ф. Тиво // Мелиорация. - 2019. - № 1 (87). - С. 63-72.

18. Тарасов, С. И. Актуальные вопросы загрязнения окружающей среды при использовании органических удобрений / С.И. Тарасов // Экологические проблемы использования органических удобрений в земледелии : сб. науч. тр. / Всероссийский науч.-исслед. ин-т орг. удобрений и торфа. - Владимир, 2015. - С. 284-294.

19. Тиво, П. Ф. Снижение загрязнения окружающей среды при внесении бесподстилочного навоза / П. Ф. Тиво, А. С. Анженков, Л. А. Саскевич // Мелиорация. - 2015. - № 1 (73). - С. 137-149.

20. Asmus, F. Therapie fur güllebelastete Boden / F. Asmus, M. Bolke // Neue Landwirtschaft. - 1993. - № 7. - P. 43-44.

21. Желязко, В. И. Использование бесподстилочного навоза на мелиорированных агроландшафтах Нечерноземья: монография / В. И. Желязко, П. Ф. Тиво, Ю. А. Мажайский. - Рязань : Мещерский фр-л Всеросс. НИИ гидротехники и мелиорации имени А. Н. Костякова, 2006. - 304 с.

22. Krutko, S. M. Reducing environmental pollution by animal manure from big farms / S. M. Krutko, P. F. Tivo // Ammonia workshop 2012 Saint Petersburg. Abating ammonia emissions in the UNECE and EECCA region. - Bilthoven: RVM (The Netherlands), 2014. P. 123-131.

23. Дегодюк, С. Э. Нитратное загрязнение окружающей природной среды животноводческими стоками промышленного свинокомплекса в зоне Полесья / С. Э. Дегодюк [и др.] // Природная среда Полесья : особенности и перспективы развития : сб. науч.. работ VI Международной научной конференции, Брест, 12-14 сентября 2012 г. / Редкол. : Н. В. Михальчук (отв. ред.) [и др.]. - Брэст: Альтернатыва, 2012. - Вып. 5. - С. 71-73.

24. Мерзлая, Г. Е. Использование органических отходов в сельском хозяйстве / Г. Е. Мерзлая // Российский химический журнал (Ж. Рос. хим. об-ва им. Д. И. Мендеелева). - 2005. - Т. XLIX, № 3. - С. 48-54.

25. География почв Беларуси: учебное пособие / Н. В. Клебанович [и др]. - Минск: БГУ, 2009. - С. 72.

26. Кирпичникова, Н. В. Многолетняя динамика содержания азота и фосфрора в грунтовых водах водосбора / Н. В. Кирпичникова,
Е. Е. Лапина, В. В. Кудряшова // Водные ресурсы. - 2020. - Том 47, № 5. - C. 536-545.

27. Ахметьева, Н. П. Экологическое состояние природных вод водосбора Иваньковского водохранилища и пути по сокращению их загрязнений / Н. П. Ахметьева, Е. Е. Лапина, М.В. Лола. - М. ЛКИ, 2008. $-240 \mathrm{c}$

28. Ахметьева, Н. П. Загрязнение грунтовых вод удобренииями / Н. П. Ахметьева, М. В. Лола, А. Г. Горецкая. - М. : Наука, 1991. $100 \mathrm{c}$.

29. Додолина, В. Т. Очистка сточных вод на полях орошения / В. Т. Додолина // Земледельческие поля орошения как способ охраны водных ресурсов от загрязнения сточными водами. - М., 1981. - C. 27-38

30. Желязко, В. И. Эфрфективность почвенно-биологической очистки стоков свино-комплекса на серых лесных почвах / В. И. Желязко [и др.] // Основные направления получения экологически чистой продукции растениеводства : тез. докл. Республ. науч.-произв. конф. - Горький, 1992. - С. 175-176.

31. Неверова, О. П. Современные методы утилизации навозосодержащих и сточных вод / О.П. Неверова [и др.] // Аграрный вестник Урала. - 2015. - № 1(131). - С. 86-90.

32. Волчек, А. А. Влияние орошения сточными водами свиноводческих комплексов на биогенное загрязнение грунтовых вод (на примере ОАО «СГЦ «Западный») / А. А. Волчек [и др.] // Мелиорация. - 2017. - № 2. - С. 51-58.

33. Клебанович, Н. В. Основы химической мелиорации почв: курс лекций для студентов географического факультета / Н. В. Клебанович. - Минск, 2005. - 100 с.

34. Godlinski, F. Phosphorus and trace metal distribution under confined cattle feeding operations in Southern Alberta / F. Godlinski [et al.]. /I Landbauforschung. - 2011. - Vol. 61, № 3. - P. 249-259.

35. Методические рекомендации по технологическому проектированию систем удаления и подготовки к использованию навоза и помета : РД-АПК 1.10.15.02-17. - Введ. 01.09.2017. - М. : Министерство сельского хозяйства Российской Федерации, 2017. - 167 с.

36. Троц, Н. М. Влияние обработки почвы на аккумуляцию тяжелых металлов в пахотном горизонте и фитомассе зерновых культур Самарского Заволжья / Н. М. Троц, В. Б. Троц, С. В. Обущенко // Аграрная Россия. - 2012. - № 12. - С. 7-10.

37. Логинов, А. А. Использование почв, загрязненных тяжелыми металлами, в сельскохозяйственном производстве / А. А. Логинов, И. Н. Лыков, А. С. Голофтеева // Проблемы региональной экологии. - 2017. - № 5. - С. 23-27.

38. Коваленко, С. Г. Влияние $\mathrm{Cd}$ и Рb на продуктивность кукурузы (на зеленый корм) при корневом и некорневом поступлении их в растения / С. Г. Коваленко // Совершенствование методологии агрохимических исследований. - М. : МГУ, 1997. - С. 384-388.

39. Ягодин, Б. А. Кадмий в системе почва - удобрения - растения животные организмы и человек / Б. А. Ягодин, С. Б. Виноградова, В.В.Говорина // Агрохимия. - 1989. - № 5. - С. 118-131.

40. Степанова, Л. П. Экологическая характеристика антропогеннотрансформированных почв, загрязненных тяжелыми металлами / Л. П. Степанова, Е. В. Яковлева, А. В. Писарева // Агрохимия. 2016. - № 12. - C. 60-67.

41. Селюкова, С. В. Тяжелые металлы в органических удобрениях / С. В. Селюкова // Агрохимический вестник. - 2016. - № 5. C. $47-51$.

42. Иванов, А. И. Тяжелые металлы в песчаных почвах Псковской области / А. И. Иванов [и др.] // Агрохимия. - 2017. - № 1. - С. 71-79.

43. Кабата-Пендиас, А. Микроэлементы в почвах и растениях / А. Кабата-Пендиас, Х. Пендиас. - М. : Мир, 1989. - С. 166-180.

44. Nort, A. E. Environmentally relerant concentrations of aminopolycarboxylate chelating agents mobilize $\mathrm{Cd}$ from humic acid / A. E. Nort [et al.]. // J. Enviro.Sci. - 2017. - Vol. 57. - P. 249-257.

45. Степанова, Л. П. Экологическая оценка влияния использования навозных стоков КРС на состояние окружающей среды / Л. П. Степанова // Вестник РУДН. - 2012. - № 2. - С. 79-86.

\section{References}

1. Obrashchenie s othodami [Elektronnyj resurs] / Ministerstvo prirodnyh resursov i ohrany okruzhayushchej sredy Respub. Be-larus'. Minsk, 2021. - Rezhim dostupa : http://www.minpri-roda.gov.by. Data dostupa : 12.01.2021.

2. Kuznecov, E. V. Pererabotka othodov zhivotnovodcheskih predpriyatij / E. V. Kuznecov // Elektronnyj setevoj politematicheskij zhurnal «Nauchnye trudy KubGTU». - 2019. - № 3. - S. 864-873. 
3. Zhelyazko, V. I. Ispol'zovanie bespodstilochnogo navoza na melioriruemyh agro-landshaftah. Teoriya i praktika : monografiya / V. I. Zhelyazko, P. F. Tivo. - Minsk, 2006. - $296 \mathrm{~s}$.

4. Dabahova, E. V. Agroekologicheskie problemy ispol'zovaniya organicheskih udobrenij v sel'skom hozyajstve / E. V. Dabahova, I. A. Pitina // Agrohimicheskij vestnik. - 2017. - №2. - S. 10-14.

5. Ob obrashchenii s othodami: Zakon Resp. Belarus', 20 iyulya $2007 \mathrm{~g}$., №271-Z v red. Zakona Resp. Belarus' ot 02 aprelya $2019 \mathrm{~g}$. // Konsul'tant Plyus: Belarus' [Elektronnyj resurs] / Nac. centr pravovoj inform. Resp. Belarus'. - Minsk, 2020.

6. Nacional'naya strategiya ustojchivogo social'no-ekonomicheskogo razvitiya Respubliki Belarus' na period do 2030 goda [Elektronnyj resurs]. 2017. - Rezhim dostupa : https://www.economy.gov.by/uploads/files/NSUR2030/Natsionalnaja-strategija-ustojchivogo-sotsialno-ekonomicheskogo-razvitija-Respubliki-Belarus-na-period-do-2030-goda.pdf. Data dostupa : 27.12.2020.

7. Struk, M. I. Ocenka sredoformiruyushchej roli ob"ektov zhivotnovodstva v Pripyatskom Poles'e / M. I. Struk // Prirodopol'zovanie. - 2015. № 27. - S. 24-32.

8. Bad'ina, V. M. Zagryaznenie pochv i ih ohrana / V. M. Bad'ina // Ekologoekonomicheskie problemy reformirovaniya agropro-myshlennogo kompleksa Belorusskogo Poles'ya. - 2001. - Vyp.1. - S.212-220.

9. Tivo, P. F. Ekologicheskie aspekty ispolzovaniya bespodstilochnogo navoza / P. F. Tivo [i dr.] // Melioraciya. - 2010. - № 2 (64). - S. 129-138.

10. Dyba, E. V. Obzor i analiz izvestnyh sposobov vneseniya zhidkogo navoza / E. V. Dyba, Yu. L. Salapura // Nauchno-tekhnicheskij progress v sel'skohozyajstvennom proizvodstve : materialy Mezhdunar. nauch.tekhnich. konf., posvyashch. 70-letiyu so dnya obrazovaniya RUP «NPC NAN Belarusi po mekhanizcii sel'skogo hozyajstva», Minsk, 18-20 okt. $2017 \mathrm{~g} /$ Belaruskaya navuka. - Minsk, 2017. - S. 185-189.

11. Davydov, A. S. Ispol'zovanie bespodstilochnogo navoza dlya udobritel'nyh polivov / A. S. Davydov, R. P. Vorob'eva // Prirodoobustrojstvo. - 2008. - № 4. - S. 25-28.

12. Mironov, V. V. Voprosy zashchity okruzhayushchej sredy ot zagryaznenij othodami zhivotnovodstva i pticevodstva / V. V. Mironov // Innovacii v sel'skom hozyajstve. - 2016. - № 5 (20). - S. 56-59.

13. Stepuk, L. Ya. O neobhodimosti aktivizacii resheniya ekologicheskih problem vokrug zhivotnovodcheskih kompleksov / L. Ya. Stepuk, A. N. Kavgarenya // Sovremennye tekhnologii i kompleksy tekhnicheskih sredstv $\mathrm{v}$ sel'skohozyajstvennom proizvodstve : materialy Mezhdunar. nauch.-praktich. konf., Minsk, 2005 / UO BGATU ; pod obshch. red. L. V. Misuna. - Minsk, 2005. - S. 165-167.

14. Sistema primeneniya udobrenij / S.F. SHekunova [i dr.]. - Gorki Belorusskaya gosudarstvennaya sel'skohozyajstvennaya akademiya, 2004. $-135 \mathrm{~s}$.

15. Skopinceva, T. V. Problemy bor'by s evtrofikaciej vo-doemov v sluchae sbrosa fosforsoderzhashchih stochnyh vod / T. V. Skopinceva, A. G. Sinel'nikov // Fundamental'nye i prikladnye issledovaniya v sovremennom mire. - 2014. - Tom 3, № 8. - S. 27-30.

16. Kirejcheva, L. V. Ocenka diffuznogo zagryazneniya ot sel'skohozyajstvennyh territorij v bassejne Verhnej Volgi i razrabotka meropriyatij / L. V. Kirejcheva [i dr]. // Vodnye resursy. - 2020. - Tom 47, № 5. - S. 523-535.

17. Tivo, P. F. Zagryaznenie okruzhayushchej sredy tyazhelymi metallami, soderzhashchimisya v zhivotnovodcheskih stokah / P. F. Tivo // Melioraciya. - 2019. - № 1 (87). - S. 63-72.

18. Tarasov, S. I. Aktual'nye voprosy zagryazneniya okruzhayushchej sredy pri ispol'zovanii organicheskih udobrenij / S. I. Tarasov // Ekologicheskie problemy ispol'zovaniya organicheskih udobrenij $v$ zemledelii : sb. nauch. tr. / Vserossijskij nauch.-issled. in-t org. udobrenij i torfa. - Vladimir, 2015. - S. 284-294.

19. Tivo, P. F. Snizhenie zagryazneniya okruzhayushchej sredy pri vnesenii bespodstilochnogo navoza / P. F. Tivo, A. S. Anzhenkov, L. A. Saskevich // Melioraciya. - 2015. - № 1 (73). - S. 137-149.

20. Asmus, F. Therapie fur güllebelastete Boden / F. Asmus, M. Bolke // Neue Landwirtschaft. - 1993. - № 7. - P. 43-44.

21. Zhelyazko, V. I. Ispol'zovanie bespodstilochnogo navoza na meliorirovannyh agrolandshaftah Nechernozem'ya: mono-grafiya / V. I. Zhelyazko, P. F. Tivo, Yu. A. Mazhajskij. - Ryazan' : Meshcherskij f-I Vseross. NII gidrotekhniki i melioracii imeni A. N. Kostyakova, 2006. - $304 \mathrm{~s}$.

22. Krutko, S. M. Reducing environmental pollution by animal manure from big farms / S. M. Krutko, P. F. Tivo // Ammonia workshop 2012 Saint Petersburg. Abating ammonia emissions in the UNECE and EECCA region.Bilthoven: RVM (The Netherlands), 2014. - P. 123-131.

23. Degodyuk, S. E. Nitratnoe zagryaznenie okruzhayushchej prirodnoj sredy zhivotnovodcheskimi stokami promyshlennogo svinokom- pleksa v zone Poles'ya / S. E. Degodyuk [i dr.] // Prirodnaya sreda Poles'ya : osobennosti i perspektivy razvitiya : sb. nauch.. rabot VI Mezhdunarodnoj nauchnoj konferencii, Brest, 12-14 sentyabrya 2012 g. / Redkol. : N. V. Mihal'chuk (otv. red.) [i dr.]. - Brest: Al'ternatyva, 2012. - Vyp. 5. - S. 71-73.

24. Merzlaya, G. E. Ispol'zovanie organicheskih othodov v sel'skom hozyajstve / G. E. Merzlaya // Rossijskij himicheskij zhurnal (ZH. Ros. him. ob-va im. D. I. Mendeeleva). - 2005. - T. XLIX, № 3. - S. 48-54.

25. Geografiya pochv Belarusi: uchebnoe posobie / N. V. Kleba-novich [i dr]. - Minsk: BGU, 2009. - S. 72.

26. Kirpichnikova, N. V. Mnogoletnyaya dinamika soderzhaniya azota i fosfora v gruntovyh vodah vodosbora / N. V. Kirpichnikova, E. E. Lapina, V.V. Kudryashova // Vodnye resursy. - 2020. - Tom 47, № 5. S. $536-545$.

27. Ahmet'eva, N.P. Ekologicheskoe sostoyanie prirodnyh vod vodosbora Ivan'kovskogo vodohranilishcha i puti po sokrashcheniyu ih zagryaznenij / N. P. Ahmet'eva, E. E. Lapina, M. V. Lola. - M. : LKI, 2008 - 240 s.

28. Ahmet'eva, N. P. Zagryaznenie gruntovyh vod udobreniiyami / N. P. Ahmet'eva, M. V. Lola, A.G. Goreckaya. - M. : Nauka, 1991. - 100 s.

29. Dodolina, V. T. Ochistka stochnyh vod na polyah orosheniya / V.T. Dodolina // Zemledel'cheskie polya orosheniya kak sposob ohrany vodnyh resursov ot zagryazneniya stochnymi vodami. - M., 1981. - S. 27-38.

30. Zhelyazko, V. I. Effektivnost' pochvenno-biologicheskoj ochistki stokov svino-kompleksa na seryh lesnyh pochvah / V.I. ZHelyazko [i dr.] // Osnovnye napravleniya polucheniya ekologicheski chistoj produkcii rastenievodstva : tez. dokl. Respubl. nauch.-proizv. konf. - Gor'kij, 1992. - S. 175-176.

31. Neverova, O. P. Sovremennye metody utilizacii navozosoderzhashchih i stochnyh vod / O. P. Neverova [i dr.] // Agrarnyj vestnik Urala. 2015. - № 1(131). - S. 86-90.

32. Volchek, A. A. Vliyanie orosheniya stochnymi vodami svinovodcheskih kompleksov na biogennoe zagryaznenie gruntovyh vod (na primere OAO «SGC «Zapadnyj») / A. A. Volchek [i dr.] // Melioraciya. 2017. - № 2. - S. 51-58.

33. Klebanovich, N. V. Osnovy himicheskoj melioracii pochv: kurs lekcij dlya studentov geograficheskogo fakul'teta / N. V. Klebanovich. Minsk, 2005. - $100 \mathrm{~s}$.

34. Godlinski, F. Phosphorus and trace metal distribution under confined cattle feeding operations in Southern Alberta / F. Godlinski [et al.]. /I Landbauforschung. - 2011. - Vol. 61, № 3. - P. 249-259.

35. Metodicheskie rekomendacii po tekhnologicheskomu proektirovaniyu sistem udaleniya i podgotovki $k$ ispol'zovaniyu navoza i pometa : RDAPK 1.10.15.02-17. - Vved. 01.09.2017. - M. : Ministerstvo sel'skogo hozyajstva Rossijskoj Federacii, 2017. - $167 \mathrm{~s}$.

36. Troc, N. M. Vliyanie obrabotki pochvy na akkumulyaciyu tyazhelyh metallov v pahotnom gorizonte i fitomasse zernovyh kul'-tur Samarskogo Zavolzh'ya / N. M. Troc, V. B. Troc, S. V. Obushchenko // Agrarnaya Rossiya. - 2012. - № 12. - S. 7-10.

37. Loginov, A. A. Ispol'zovanie pochv, zagryaznennyh tyazhelymi metallami, v sel'skohozyajstvennom proizvodstve / A. A. Loginov, I. N. Lykov, A. S. Golofteeva // Problemy regional'noj ekologii. - 2017. № 5. - S. 23-27.

38. Kovalenko, S. G. Vliyanie $\mathrm{Cd}$ i Pb na produktivnost' kukuruzy (na zelenyj korm) pri kornevom i nekornevom postuplenii in v rasteniya / S. G. Kovalenko // Sovershenstvovanie metodologii agrohimicheskih issledovanij. - M. : MGU, 1997. - S. 384-388.

39. Yagodin, B. A. Kadmij v sisteme pochva - udobreniya - rasteniya zhivotnye organizmy i chelovek / B. A. YAgodin, S. B. Vinogradova, V. V. Govorina // Agrohimiya. - 1989. - № 5. - S. 118-131.

40. Stepanova, L. P. Ekologicheskaya harakteristika antropogennotransformirovannyh pochv, zagryaznennyh tyazhelymi metallami / L. P. Stepanova, E. V. Yakovleva, A. V. Pisareva // Agrohimiya. 2016. - № 12. - S. 60-67.

41. Selyukova, S. V. Tyazhelye metally $v$ organicheskih udobreniyah / S. V. Selyukova // Agrohimicheskij vestnik. - 2016. - № 5. - S. 47-51.

42. Ivanov, A. I. Tyazhelye metally $v$ peschanyh pochvah Pskovskoj oblasti / A. I. Ivanov [i dr.] // Agrohimiya. - 2017. - № 1. - S. 71-79.

43. Kabata-Pendias, A. Mikroelementy $v$ pochvah i rasteniyah / A. KabataPendias, H. Pendias. - M. : Mir, 1989. - S. 166-180.

44. Nort, A. E. Environmentally relerant concentrations of aminopolycarboxylate chelating agents mobilize $\mathrm{Cd}$ from humic acid / A. E. Nort [et al.]. // J. Enviro.Sci. - 2017. - Vol. 57. - P. 249-257.

45. Stepanova, L. P. Ekologicheskaya ocenka vliyaniya ispol'zovaniya navoznyh stokov KRS na sostoyanie okruzhayushchej sredy / L. P. Stepanova // Vestnik RUDN. - 2012. - № 2. - S. 79-86.

Материал поступил в редакцию 15.05.2021 